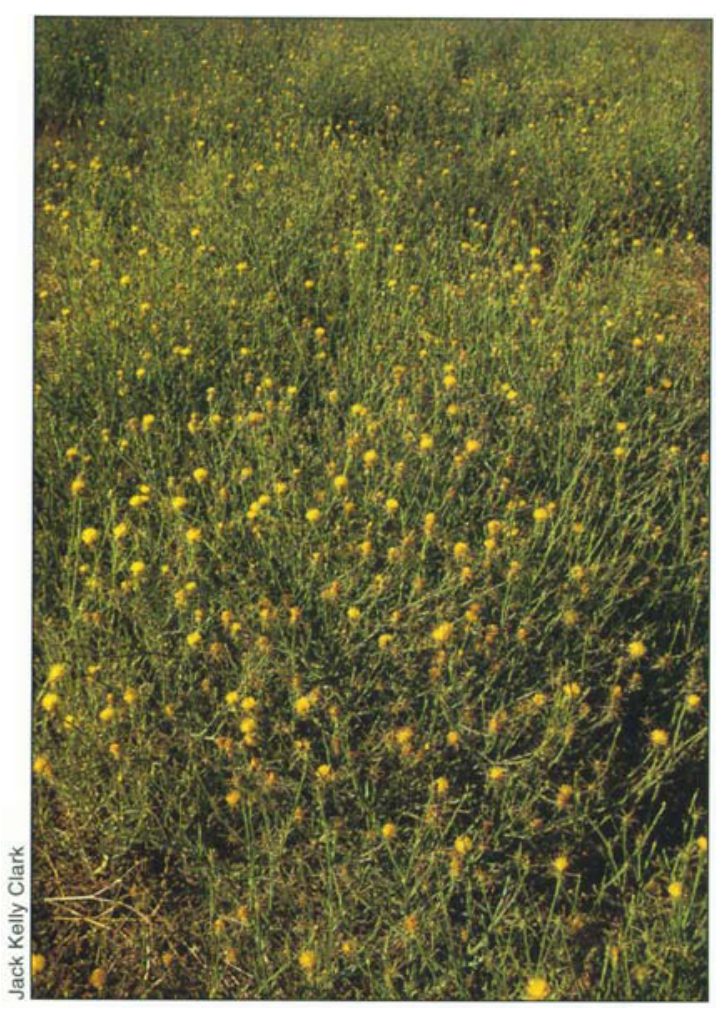

Ongoing research projects integrate chemical, mechanical, cultural and biological techniques to control yellow starthistle, a prolific weed now infesting between 10 million and 15 million acres in California. With many options available to land managers, developing a long-term, strategic management plan most suitable to a specific area can be complicated. It requires careful consideration of the advantages and disadvantages of each option and how best to incorporate appropriate ones into an effective program. Management strategies include timely mowings, grazing, clover plantings, biological control insects, prescribed burning and selective applications of herbicides. In addition to new developments in the management of yellow starthistle, public awareness of invasive weed issues has translated into major legislative changes that should encourage and assist private and public landowners and managers to initiate long-term programs to prevent and manage invasive weeds, particularly yellow starthistle.

\title{
Integrated strategies offer site-specific control of yellow starthistle
}

\author{
Joseph M. DiTomaso a Guy B. Kyser $\square$ Steve B. Orloff
}

Steven F. Enloe

A mong the numerous weed problems threatening noncrop areas of California, yellow starthistle (Centaurea solstitialis) is among the most pervasive. Several articles have described its introduction from Eurasia and subsequent exponential spread in California (Gerlach 1997; Pitcairn et al. 1997). Yellow starthistle (YST) is the most widely distributed noncrop weed in the state, occurring in 56 of 58 counties and infesting between $15 \%$ and $22 \%$ of the surface area of the state (Pitcairn et al. 1997; Balciunas and Villegas 1999), with the potential to spread further in coastal and mountainous regions.

A number of control options are available for the management of YST, including grazing, mowing, clover or perennial grass reseeding, burning, chemical and biological control. Recent studies by UC researchers have emphasized the development of integrated systems for the long-term sustainable management of YST. Such systems include various combinations of these newly developed techniques. The objective of using an integrated approach is to provide ranchers and land managers with economical and sustainable management programs that maximize forage quality and quantity, or preserve ecosystem integrity, while also reducing the susceptibility of their lands to invasion or reinvasion by other noxious weeds.

\section{Integrated treatment approach}

Our study under way near Yreka emphasizes the combination of herbicides, biological control and competitive perennial grass reseeding. UC Davis researchers, in collaboration with farm advisors in Siskiyou County, have employed a late-winter glyphosate treatment for annual-grass control in the first year and 1 to 3 consecutive years of treatment with the herbicide clopyralid for starthistle control. In the first year, the herbicide treatments were followed by spring drill seeding with perennial wheatgrass ('Luna' pubescent; Thinopyrum intermedium). The goal of this revegetation project is to develop sustainable, high-quality range conditions and

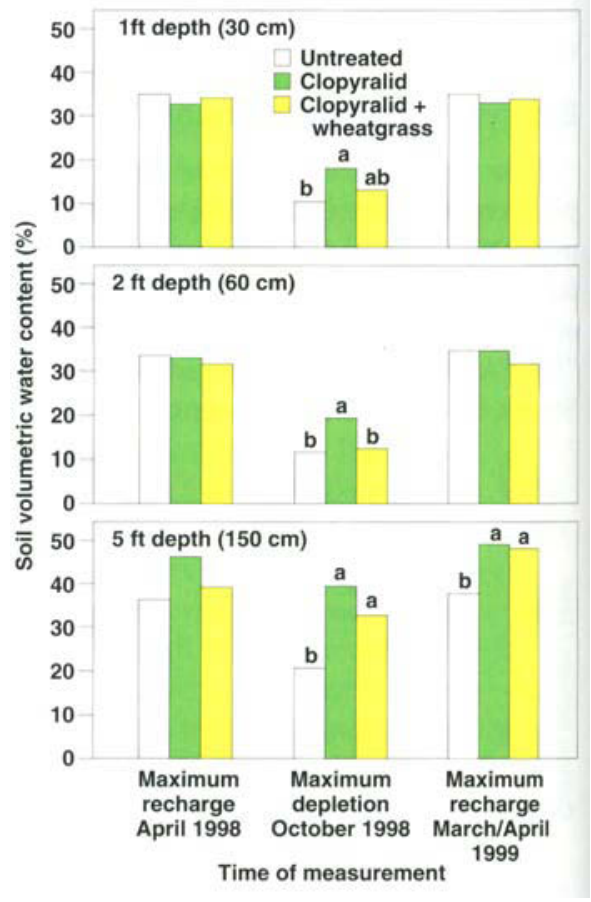

Fig. 1. Comparison of soil moisture at three soll depths at times of maximum recharge in 1998 and 1999 and maximum depletion in 1998 in untreated control, clopyralid-treated and clopyralid + pubescent wheatgrass plots. Within each cluster significant differences $(\alpha=0.05)$, if any, are indicated by different letters. 
wildlife habitat capable of providing long-term starthistle control without the need for continued herbicide treatments.

Although this project is ongoing, preliminary results are promising. After 2 or 3 years of clopyralid treatment, with or without pubescent wheatgrass, YST cover was dramatically reduced (table 1 ). In contrast, only 1 year of treatment did not provide sustainable control. Interestingly, a first-year-only treatment with clopyralid and glyphosate was sufficient to allow wheatgrass establishment. In this case, the wheatgrass provided some level of starthistle control in subsequent years, but was not as effective as 2 years of clopyralid treatment with wheatgrass.

\section{Soil moisture variations}

In the same experiment, we used a neutron probe to measure soil-water depletion during the growing season, as well as soil-moisture recharge during the rainy season. Plots treated with clopyralid and not seeded with pubescent wheatgrass were dominated by annual species, particularly grasses. Soil-moisture use in these plots was significantly less than in the untreated, heavily infested control plots at all depths (fig. 1). By comparison, plots treated with clopyralid and drillseeded with pubescent wheatgrass used soil moisture similar to control plots at 1-foot and 2-foot depths, but used significantly less moisture at 5 feet. Furthermore, deep soil moisture in the starthistle-infested control plots did not recharge during the 1998-1999 rainy season to the level measured in the clopyralidtreated plots.

\section{Weed depletes soil moisture}

These results indicate that YST infestations can deplete soil moisture to a greater degree than rangeland dominated by annual grasses or perennial wheatgrass. Wheatgrass appears to be able to use soil moisture at the shallow and intermediate soil depths, but not at the deeper soil levels. Most significantly, heavy infestations of YST can lead to inadequate deep, soil-

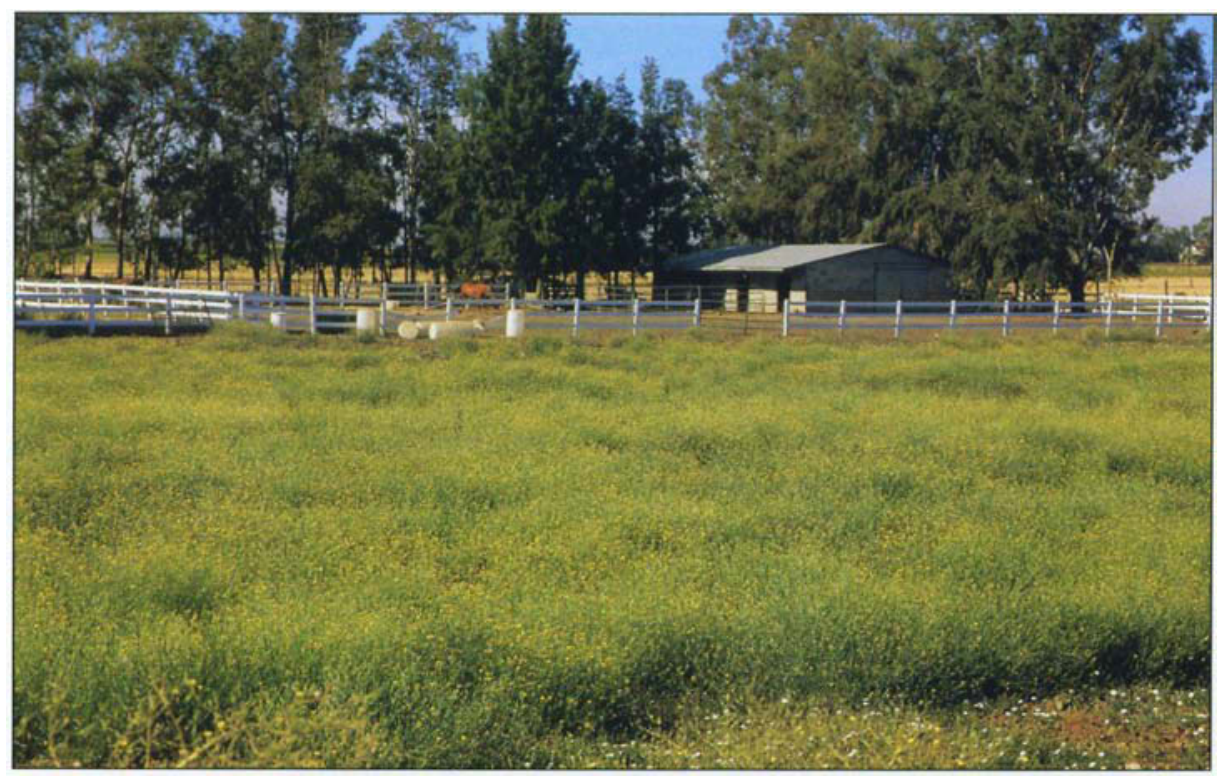

A number of control options are available for managing yellow starthistle, including combinations of these newly developed techniques. moisture recharge. This can have a negative impact on restoration efforts using trees, shrubs or deep-rooted perennials.

On severely degraded rangeland, combining clopyralid treatment and wheatgrass seeding can be very effective in suppressing YST seed production and may provide a more effective long-term solution than applying clopyralid alone. This strategy is also compatible with YST biocontrol agents, which are well established at the Yreka research site. With the integration of these insects, it is possible that starthistle seed production will be reduced, further slowing the re-infestation rate.

\section{Tools available for control}

Although clopyralid is an important tool for managing YST, several other methods can be employed in a long-term management plan. For example, Thomsen et al. (1993) develpractices for YST control on California grasslands. They showed that properly timed intensive grazing - in May and June by cattle, sheep or goats resulted in reduced YST growth, summer and fall canopy-cover survival and reproductive capacity. This approach was most successful when YST was grazed after the stems had bolted, but before the spiny seedheads developed. In addition to controlling starthistle, Thomsen et al. (1993) also reported that grazing the weed during the bolting stage could provide palatable high-protein forage. This can be particularly important in late spring and early summer when many other annual species have senesced. oped livestock grazing management

TABLE 1. Combined effect of 1,2 or 3 years of clopyralid treatment and pubescent wheatgrass reseeding on yellow starthistle control and vegetative cover in 1999

\begin{tabular}{|c|c|c|c|c|c|c|}
\hline \multirow[b]{2}{*}{ Treatment } & \multicolumn{4}{|c|}{$\%$ Vegetative cover } & \multicolumn{2}{|c|}{ Yellow starthistle } \\
\hline & $\begin{array}{c}\text { Yellow } \\
\text { starthistle }\end{array}$ & $\begin{array}{c}\text { Pubescent } \\
\text { wheatgrass }\end{array}$ & $\begin{array}{c}\text { Other grasses } \\
\text { and forbs }\end{array}$ & $\begin{array}{l}\text { S Total cover } \\
\text { (excluding YST) }\end{array}$ & Biomass & $\begin{array}{c}\text { Seedhead } \\
\text { production }\end{array}$ \\
\hline & & & & & $\mathrm{g} / 0.25 \mathrm{~m}^{2}$ & no. $/ 0.25 \mathrm{~m}^{2}$ \\
\hline Untreated control & $45 a^{*}$ & $\mathrm{Oc}$ & $48 b$ & $48 b$ & $42 a b$ & 194 a \\
\hline Untreated with wheatgrass & $42 \mathrm{a}$ & $5 \mathrm{c}$ & $46 \mathrm{~b}$ & $51 \mathrm{~b}$ & $30 \mathrm{~b}$ & $145 a b$ \\
\hline Clopyralid (1 yr)† & $52 \mathrm{a}$ & $0 \mathrm{c}$ & $42 b$ & $42 \mathrm{~b}$ & $56 \mathrm{a}$ & $223 \mathrm{a}$ \\
\hline Clopyralid (2 yrs) $\dagger$ & $2 c$ & $O C$ & $88 \mathrm{a}$ & $88 \mathrm{a}$ & $24 \mathrm{bc}$ & $109 \mathrm{bc}$ \\
\hline Clopyralid (3 yrs) $\dagger$ & $\mathrm{OC}$ & $\mathrm{OC}$ & $92 \mathrm{a}$ & $92 \mathrm{a}$ & $0 \mathrm{~d}$ & $0 \mathrm{~d}$ \\
\hline Clopyralid (1 yr) + wheatgrass $\ddagger$ & ; $16 \mathrm{~b}$ & $34 \mathrm{~b}$ & $36 \mathrm{~b}$ & $68 a b$ & $10 \mathrm{~cd}$ & $47 \mathrm{~cd}$ \\
\hline Clopyralid $(2 \mathrm{yr})+$ wheatgrass & $2 \mathrm{c}$ & $32 \mathrm{~b}$ & $49 \mathrm{~b}$ & $81 \mathrm{a}$ & $2 d$ & $10 \mathrm{~d}$ \\
\hline Clopyralid $(3 \mathrm{yr})+$ wheatgrass & $\mathrm{Oc}$ & $44 \mathrm{a}$ & $39 \mathrm{~b}$ & $83 \mathrm{a}$ & $0 \mathrm{~d}$ & $0 \mathrm{~d}$ \\
\hline
\end{tabular}

"Means followed by the same letter within each column are not significantly different at $5 \%$ level. †Treated with clopyralid ( 1.0 to $1.5 \mathrm{oz}$ ae/acre) $1 \mathrm{yr}=1997$ only; 2 yrs = 1997 and 1998 ; and 3 yrs = 1997, 1998 and 1999.

¥All clopyralid + wheatgrass treatments received a first-year glyphosate ( $1 \mathrm{lb}$ ae/A) application for annual grass control. 


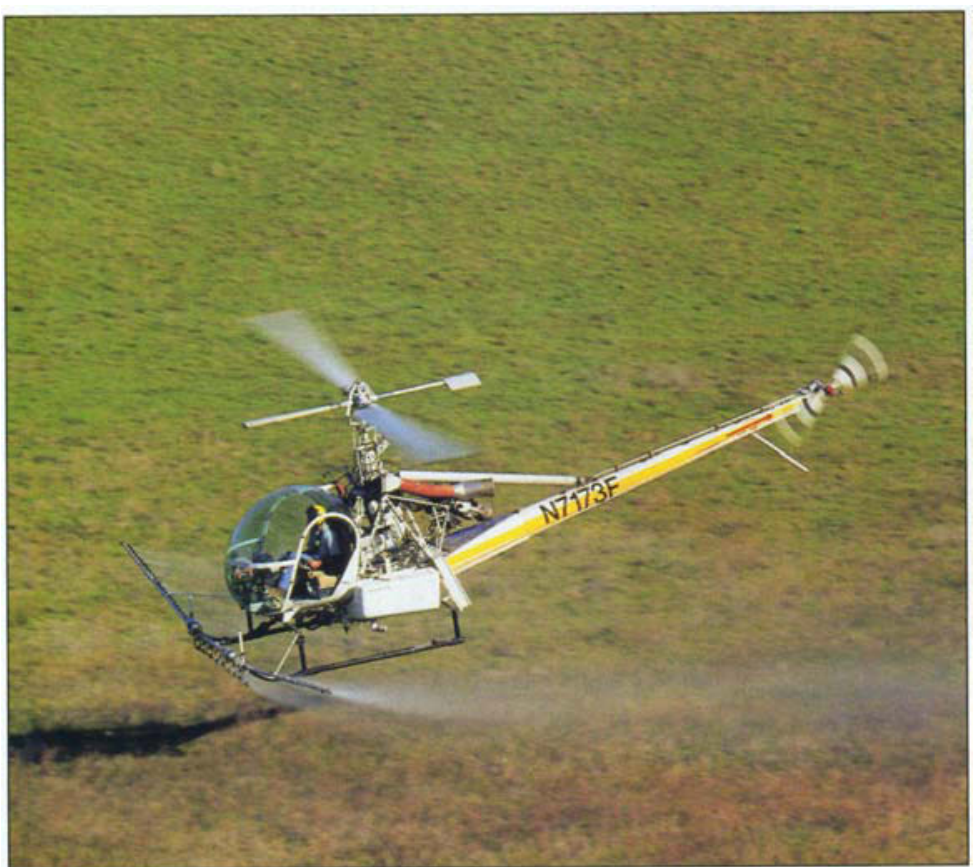

Aerial application of herbicide to yellow starthistle-infested rangeland. Herbicides reduce the starthistle population, thus depleting much of the seedbank.

Thomsen et al. (1997) and Benefield et al. (1999) demonstrated the successful use of mowing for YST control. Thomsen et al. (1997) consistently demonstrated over $90 \%$ control of YST using two timely mowings per year over a 3-year period. Benefield et al. (1999) also showed that mowing conducted at the early flowering stage, before viable seed production, was most effective in controlling YST. However, they also demonstrated that the success of mowing as a control strategy not only depended upon the timing of the mowing, but also on the plant's growth form and branching pattern. Plants with an erect, high-branching growth form were effectively controlled by a single mowing at the early flowering stage, while sprawling, low-branching plants were not controlled even with repeated mowings at proper intervals.

Combinations of grazing, mowing and clover plantings have been successfully integrated to manage YST (Thomsen et al. 1997). For example, seeding with subterranean clover ( $\mathrm{Tr}$ folium subterraneum), grazing three times and mowing once at the early flowering stage reduced YST seed production by $93 \%$. In another experiment, two timely repeated mowings combined with a subterranean clover planting gave nearly complete control of YST.

DiTomaso et al. (1999a) showed that prescribed burning of infested rangelands or wildlands can provide excellent control of YST. As with mowing, the success of this method depends on proper timing. Burning in midsummer following seed dispersal and

senescence of desirable grasses and forbs, but before viable seed production in YST, resulted in significant vegetative changes from a starthistledominated area to a more diverse grassland with dramatic increases in native forbs and perennial grasses. After 3 consecutive years of burning, starthistle control was greater than $90 \%$. The success of this project has led many land managers to incorporate a controlled summer burn into their YST management programs.

State and federal researchers have sought and subsequently introduced YST biological-control insects into California. Since the 1986 release of Bangasternus orientali, the first YST control insect in California, there have been five additional insects released and established in the state. Of the insects released and established in California for YST control, all produce larvae that develop within the seedhead and feed on seeds. Only two, however, the false peacock fly (Chaetorellia succinea) and the hairy weevil (Eustenopus villosus), have been shown to significantly impact seed production (Balciunas and Villegas 1999). The combination of these two insects can reduce seed production by $50 \%$ to $75 \%$ (Pitcairn and DiTomaso 2000). Although this level of suppression is not sufficient to provide long-term starthistle management, biological control agents can be an important component of an integrated management approach.

\section{Control option considerations}

The goal of any management plan should be not only controlling the noxious weed, but also improving the degraded community, enhancing the utility of that ecosystem and preventing invasion or reinvasion by other noxious weed species. This usually requires a long-term, integrated management plan. A number of considerations can influence the choice of options; most important is the landuse objective. This can include forage production, preservation of native or endangered plant species, wildlife habitat development or recreational land maintenance. Selection of the proper management program and tools may also depend on other factors including weed species and associated vegetation, initial density of YST infestation, effectiveness of the control techniques, years necessary to achieve control, environmental considerations, chemical-use restrictions, topography, climatic conditions and relative cost of the control techniques.

In many cases, it may take 3 or more years of intensive management to significantly reduce a YST population. Although uncommon, it is possible to substantially reduce the infestation with 1 year of control. However, it is believed that a more established starthistle population, with a large residual seedbank, will require a longerterm management program.

Perhaps the best method for developing a YST management program is to consider the advantages and disadvantages of each approach and to judge how each option may best fit into a long-term program. It is possible that several different strategies can prove successful in a given location. The consistent components of a successful program should include persistence, flexibility and, most importantly, preventing new seed recruitment.

\section{Chemical control}

Herbicides can provide effective and reliable control of YST. In addi- 
tion, they do not appear to harm biological-control insect populations (Pitcairn and DiTomaso 2000). Clopyralid is particularly effective on YST as a preemergence and postemergence compound. It is very selective, used at very low rates and has low toxicity to animals. However, depending on the timing of application, it can injure most species in the legume family or Fabaceae (Leguminosae), as well as the sunflower family (Asteraceae); this may be undesirable in a control program that is trying to increase native plant diversity or enhance a threatened nativeplant population susceptible to the herbicide. Furthermore, continuous use of clopyralid may lead to selection for resistant biotypes of YST or ultimately selection for other equally undesirable invasive annual grasses such as medusahead (Taeniatherum caputmedusae), ripgut brome (Bromus diandrus), downy brome (Bromus tectorum), or barbed goatgrass (Aegilops triuncialis).

In most circumstances, however, clopyralid can be an important component in a YST management program. For example, clopyralid is often a very effective first-year option in a multiyear program. This is particularly true in heavily infested areas. The herbicide can substantially reduce the starthistle population, thus depleting much of the seedbank. Because clopyralid is typically used from late winter to very early spring when the competitive interactions for soil moisture are minimal, the control of YST will result in high grass-forage production during that growing season (DiTomaso et al. 1999b).

If YST-seedling numbers in the second winter are also very high, a second year of treatment may be needed. However, in subsequent years, it may be more advantageous to delay the use of clopyralid or other preemergence herbicides until the extent of the prob-

\begin{abstract}
$\Delta$ Herbicides.can provide effective and reliable control of YST. In addition, they do not appear to harm biological-control insect populations.
\end{abstract}

Bangasternus orientalis was the first starthistle-control insect released in California in 1986.

lem can be evaluated. For example, in some instances, 1 or 2 years of control can dramatically reduce the starthistle infestation to very low or even nearly insignificant levels. In this situation, an additional application of clopyralid or another postemergence herbicide would be unnecessary.

Other herbicides used for YST control in rangelands or wildlands can include postemergence compounds such as glyphosate or 2,4-D. These compounds are not effective when used in spring, because they have no soilresidual activity and will not control YST germinating after application. However, both postemergence herbicides can be incorporated into the latter stages of a long-term management program. In particular, they are effectively used to spot-treat escaped plants or to eradicate small populations in late season when starthistle is easily visible but has yet to produce viable seed. By using spot applications in late season, total herbicide use and expenses can be reduced because only small sections or individual plants are treated. It is important to note that
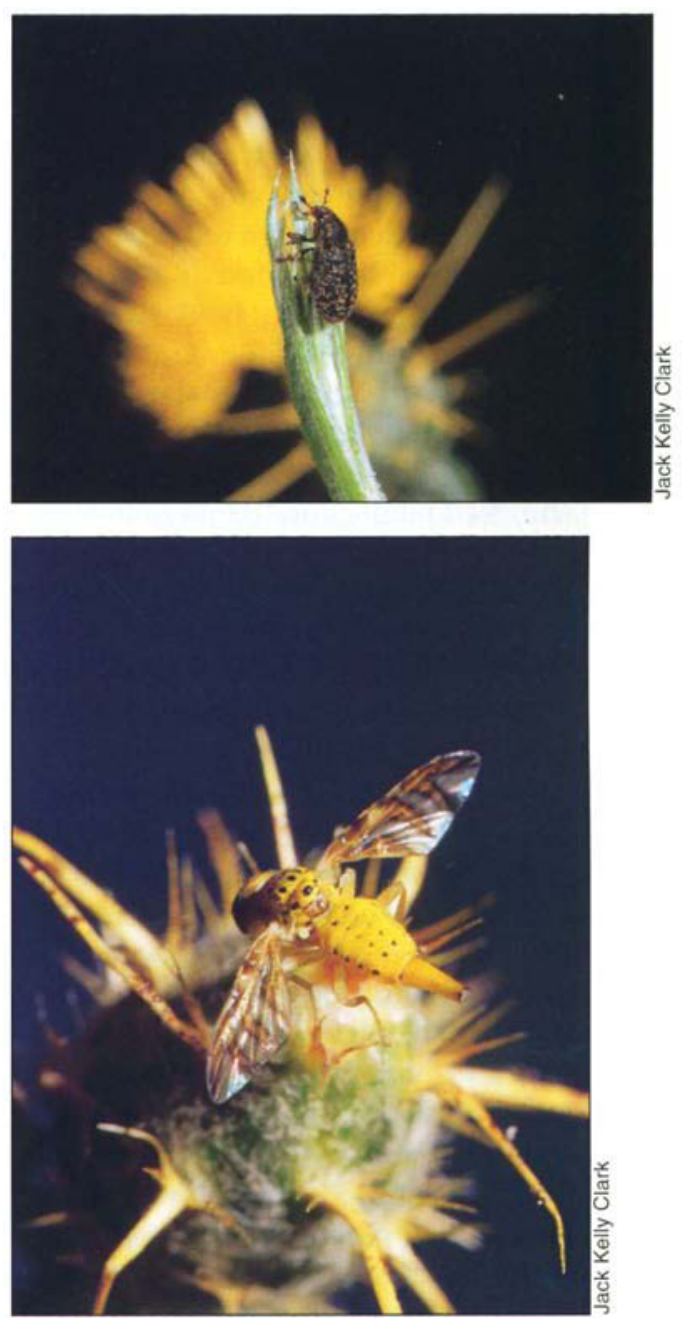

The false peacock fly (Chaetorellia succinea), above, and the hairy weevil (Eustenopus villosus), not shown, siginiflcantly reduce starthistle seed production. 


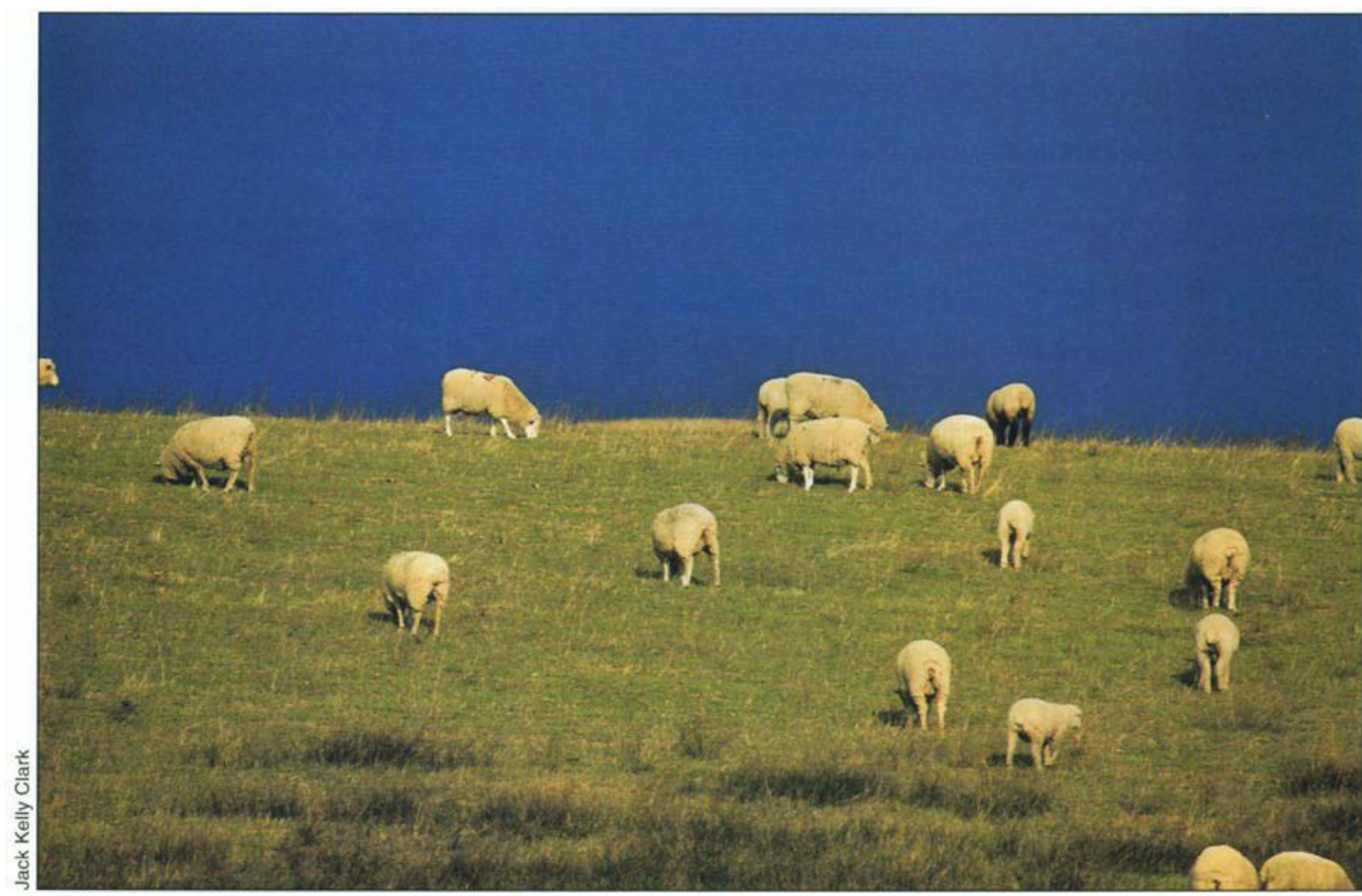

low, with only a few plants present, hand pulling may be feasible. Hand removal of individual starthistle plants prevents seed production and slows re-establishment.

\section{Prescribed burning}

Like mowing, the effectiveness of prescribed burning depends on proper timing and can be a very useful, late-season tool for YST control. In addition, it reduces the thatch layer, recycles nutrients trapped in the dried vegetation and stimulates germination or growth of many native species, particularly legumes and perennial

Intensive grazing was most successful in controlling yellow starthistle when grazing occurred after the stems had bolted, but before the spiny seedheads developed.

plants should only be treated when not exposed to severe stress. Drought stress, in particular, can reduce the efficacy of most herbicides.

Glyphosate may not be desirable in areas where preferred perennial grasses are present unless starthistle plants can be directly treated without contacting nontarget vegetation. Similarly, 2,4-D will cause damage to lateseason broadleaf species, including desirable natives.

\section{Mechanical control}

Mechanical control options for YST typically include mowing or hand pulling. Early summer tillage can also be an effective means to control starthistle, but it is not appropriate in most range or wildland situations. Although mowing can be a cost-effective method for control of starthistle, it is not feasible in many locations due to rocks and steep terrain. Mowing is not always successful as a control technique and can decrease the reproductive efforts of biocontrol insects, injure late-growing native forb species and reduce fall and winter forage for wildlife and livestock. In addition, its success depends on proper timing and the growth form of the plant. Mowing plants before the seedheads reach the spiny stage can suppress competing vegetation, thus enhancing light penetration and increasing the starthistle problem. Mowing after plants have produced viable seed will not substantially reduce the seedbank and the following year's infestation. Mowing may be an alternative strategy for small plot owners who do not wish to use herbicides.

Although a few land managers have successfully controlled YST using continuous mowing over multiple years, this control technique is best used in a second- or third-year management program or in a lightly infested area. Under these conditions, other grasses and broadleaf species capture much of the radiant light, resulting in YST plants that have few basal branches and a more elongated form. Mowing can be used very effectively on plants with this growth form (Benefield et al. 1999).

Like postemergence herbicides, mowing is a late-season tool best employed in the latter years of a longterm management program. This enables the landowner or manager to assess the level of infestation and to choose the most appropriate and costeffective option, which can include mowing. If the infestation is extremely grasses. Unfortunately, the proper time for burning is early to mid-summer, which is not feasible in some areas. Because of the summer timing requirement, prescribed burning is perhaps the riskiest option for YST management. Escaped burns can cause significant economic loss and health risks. Air quality can also be an issue when burns are near populated areas. Moreover, prescribed burning is not compatible with the establishment of insect biocontrol agents. In some areas, burning can lead to rapid invasion by other undesirable species with wind-dispersed seeds, particularly members of the sunflower family.

The ability to use repeated burning depends on climatic and environmental conditions. In areas where resources are ample and total plant biomass is abundant, multiple years of burning can provide effective control of starthistle and enhance plant diversity (DiTomaso et al. 1999a). However, in other environments or years, fuel loads may not be sufficient to allow multiple year burns. Consequently, prescribed burning may be more appropriate as part of an integrated approach. A possible combination may be a first-year clopyralid treatment, which is likely to suppress legumes and stimulate grasses, followed by a second-year burn. In the second year, 
fuel loads should be high and the previously suppressed legume populations are likely to be stimulated to grow by the burn.

\section{Biological control}

Although the current array of biological control agents for YST will not, by themselves, provide adequate control, these techniques have the greatest potential for long-term, sustainable and cost-effective management of starthistle. However, this will undoubtedly require the introduction of additional organisms that feed on roots, stems or foliage. Currently, the two most effective insects, hairy weevil (Eustenopus villosus) and the false peacock fly (Chaetorellia succinea), are widely distributed throughout California, particularly in the northern regions. These biocontrol agents should be part of any integrated management plan and we strongly encourage their establishment.

\section{Cultural control}

Proper grazing management can help to minimize spread and effectively manage noxious weeds in many rangeland systems. Different strategies can be used. For example, moderate grazing levels can minimize the impact on native plants and reduce soil disturbance; intensive grazing will counteract inherent dietary preferences of livestock, resulting in equal impacts on all forage species including weeds. Also, multispecies grazing distributes the impact more uniformly among desirable and undesirable plants.

Foraging behavior can also influence the effectiveness of a particular livestock class. Both cattle and goats can dramatically reduce YST infestations when the plants are grazed after they bolt but before they produce spiny seedheads. Cattle tend to avoid starthistle once the buds produce spines, whereas goats continue to browse plants even in the flowering stage (Thomsen et al. 1993). For this reason, goats have become a more popular animal for controlling relatively small YST infestations.

Research on the integrated role of grazing for managing noxious weeds and maintaining productive perennial grasses is ongoing.

\section{Revegetation}

Revegetation with desirable and competitive plant species is one of the best long-term sustainable methods for suppressing YST while providing high forage production or plant diversity.

The choice of species used in a revegetation effort is critical to its success. Seeded species need to be adapted to the site's soil conditions, elevation, climate and precipitation level. Intended use of the site is also an important factor. For example, if livestock grazing is the primary objective of a revegetation program, a perennial grass with high forage production may be appropriate.

In a revegetation program designed to suppress noxious weeds, a major limitation is choosing a species or combination of species that is more vigorous than the invasive weed. Only a limited number of species have proven to be aggressive enough to displace invasive species. Proper species choice varies, depending on the location and objective. Perennial bunchgrasses are among the most common species used for revegetating western grasslands, but broadleaf species such as legumes can also be used in revegetation programs to suppress rangeland weeds.

Combining species with various growth forms when designing seed mixes may also prove to be effective, although expensive. In other regions of the country, mixtures of grasses with legumes have improved the rate of microbial and soil-structure recovery compared to grasses alone. Using seed mixtures, however, may limit the options for noxious weed control, such as using selective herbicides. A revegetation program may require initial seeding with perennial grasses during
Establishment of pubescent wheatgrass dramatically reduced yellow starthistle infestation.

the weed management phase followed by subsequent reseeding with broadleaf species. Revegetation programs may take several years to be successful.

Because of the ecological diversity within California, no single species or combination of species will be effective under all circumstances. Although pubescent wheatgrass has proved successful in Siskiyou County, it may not be appropriate in other areas that lack summer rainfall. Unfortunately, few studies have been conducted on the restoration of YST-infested grasslands, particularly with native species. We need to find out what combination of species to use in various environments, which species or combination will aggressively compete with YST and how to economically establish these species.

In any revegetation program using non-native species, it is important to ensure that an introduced species will not itself become invasive. For example, Harding grass (Phalaris aquatica) is a perennial bunchgrass native to the Mediterranean region. It was planted commonly as high-value pasture forage, but has escaped to colonize wildland areas and displace native species. Even the use of native species in revegetation efforts can present potential problems. Native seed collected in one area of the state but used in a revegetation program in a different region may be geneticafly 
different, due to ecotypic variability. It has been argued that over time, as a result of genetic contamination, the native population may lose its adaptive advantage in its evolved ecosystem (Knapp and Rice 1997).

\section{Implications for the future}

Awareness of invasive species, including YST, has increased dramatically in the past few years. Numerous television and radio reports, news stories and review articles have informed the general public. As a result, pressure to manage YST and other noxious wildland weeds has led to legislative changes and increased funding opportunities.

State and federal agencies have focused much greater attention on noxious weed management. For example, CalTrans and the California Department of Food and Agriculture have recently collaborated on a large-scale YST program. The two agencies have teamed up to map the leading edge of YST encroachment along the eastern and southwestern side of the Sierra Nevada range. Their main goal is to identify areas of high priority and implement management options to prevent further movement in California.

With the confidence that options now exist for successful management of YST, California legislators introduced Assembly Bill 1168 in 1999 and Senate Bill 1740 in 2000 to create Noxious Weed Management Funds. Both bills, signed into law by Gov. Davis, fund several Weed Management Area projects, many of which will be directed at mapping or controlling YST.

The federal government has also increased its emphasis and funding in the area of invasive species, including weeds. To facilitate these efforts, a national panel of invasive weed researchers have made recommendations for improving prevention practices, public awareness, monitoring and reporting, mitigation and control and legislation and regulation of invasive plant species.

With these new opportunities, research efforts will likely focus on developing management approaches that control YST; satisfy land-use objectives within a particular area; and maintain a more diverse ecosystem capable of resisting rapid re-invasion by YST or other undesirable plants. To accomplish this, scientists will continue searching for effective biological control agents; new revegetation programs will be developed; and ecologists and land managers will incorporate integrated, weedmanagement strategies into restoration efforts.

\section{J.M. DiTomaso is Noncrop Extension} Weed Ecologist, G.B. Kyser is Staff Research Associate, S.F. Enloe is graduate student, Department of Vegetable Crops, all of UC Davis. S.B. Orloff is Farm Advisor, Siskiyou County.

\section{References}

Balciunas J, Villegas B. 1999. Two new seed head flies attack yellow starthistle. Cal Ag 53(2):8-11.

Benefield CB, DiTomaso JM, Kyser GB. 1999. Success of mowing to control yellow starthistle depends on timing and plant's branching form. Cal Ag 53(2):17-21.

DiTomaso JM, Kyser GB, Hastings MS. 1999a. Prescribed burning for control of yellow starthistle (Centaurea solstitialis) and enhanced native plant diversity. Weed Sci 47:233-42.

DiTomaso JM, Kyser GB, Orloff SB. $1999 \mathrm{~b}$. New growth regulator herbicide provides excellent control of yellow starthistle. $\mathrm{Cal} \mathrm{Ag} \mathrm{53(2):12-6.}$

Gerlach JD. 1997. How the west was lost: reconstructing the invasion dynamics of yellow starthistle and other plant invaders of western rangelands and natural areas. In: Kelly M, Wagner E, Warner P (eds.). Proc Calif Exotic Pest Plant Council 3:67-72.

Knapp EE, Rice KJ. 1997. Ecotypes of native species: how local is local in restoration plantings? In: Kelly $M$, Wagner $E$, Warner $P$ (eds.). Proc. Calif. Exotic Pest Plant Council 3:51-5.

Pitcairn MJ, DiTomaso JM. 2000. Rangeland and uncultivated areas: integrating biological control agents and herbicides for starthistle control. In: Hoddle MS (ed.). California Conference on Biological Control. UC Div Agri Nat Resources. Oakland, CA. p 6572.

Pitcairn MJ, O'Connell RA and Gendron JM. 1997. Yellow starthistle: Survey of statewide distribution. In: Woods DM (ed.). Biological Control Program Annual Summary, 1996. Calif Dept Food and Agr, Div Plant Industry, Sacramento, CA. p 53-6.

Thomsen $C D$, Vayssieres MP, Williams

WA. 1997. Mowing and subclover plantings 0

Thomsen CD, Williams WA, Vayssieres

M. 1993. Controlled grazing on annual grassland decreases yellow starthistle. Cal Ag 47(6):36-40.

\section{YST information sources}

There are a few reviews of information on the biology and control of yellow starthistle (e.g., Yellow starthistle by DiTomaso JM, Lanini WT and Thomsen CD. 1999. Pest Notes Publ. \#7402, 4 p. Available free from the Weed Science Program, Robbins Hall, Davis, CA, 95616), but most are research results published in scientific or trade journals. Although these technical papers may be valuable to scientists or land managers for the details of a specific control option, they do not provide homeowners or land managers with decision-making tools for the long-term management of starthistle.

County farm advisors can provide advice about managing invasive plants. Also, a new Web site (http://wric.ucdavis.edu/ yst/yst.html) was developed as a compendium of information on yellow starthistle history, biology, ecology and management. It is designed to help land managers weigh the advantages and disadvantages of each control option and to develop long-term management approaches for their specific situations.

With the widely generated interest in invasive plants, at least 25 regional Cooperative Weed Management Areas (WMAs) have been established in California. These WMAs are local organizations that coordinate landowners and managers from the private and public sectors for the purpose of combating common invasive weed species. In many cases, the WMAs have adopted the Range Management Advisory Committee Strategic Plan for noxious weed management. This plan emphasizes noxious weed prevention, detection, mapping and monitoring programs and promotes integrated management approaches. 